Integritas 2.2 (Fall 2013), pp. 19-25.

doi: $10.6017 /$ integritas.v2i2p19

\title{
Response to Marian K. Díaz
}

\section{William C. Mattison III}

We owe a debt of gratitude to Marian for clarifying the resplendent yet rather unspecified title of our gathering, “The Transcendent Value of the Liberal Arts." Marian focuses on contemplation and friendship, and I'd like to reflect on those two themes as well.

There are other exciting topics that Marian's paper invites further reflection upon. Some of her passing remarks could be the focus of an entire response. Perhaps my favorite was the Simone Weil quotation about prayer as attention, "the orientation of all the attention of which the soul is capable toward God." Or we could reflect upon the subtle but I think extraordinarily significant alteration she makes to our title. Rather than transcendent value she speaks of transcendent hope. A liberal arts education at a Catholic college or university does indeed witness to the transcendent. God willing, our institutions point beyond themselves to larger truths, most importantly truths about God. And such a witness does indeed engender hope, since we profess faith in a God of love, a God whose very essence is a self-giving loving communion of persons, and who invites us to and makes possible the sharing of that fullness of life. That sharing happens in a manner that is only complete in a life that transcends this present life, but also in a manner that is transformative of our individual and communal lives in this world. And this is indeed a source of hope. ${ }^{\mathrm{I}}$

So there is indeed much here. But I'd like to continue Marian's reflections on contemplation and friendship as well as the relationship between them, as they are

1 See Dominic Doyle's fine recent book on how hope can both point us beyond this life and yet be fully transformative of our activities in this life: The Promise of Christian Humanism: Thomas Aquinas on Hope (Crossroads, 2012).

William C. Mattison III is an Associate Professor of Moral Theology as well as Associate Dean of Undergraduate Studies at the School of Theology and Religious Studies at the Catholic University of America. He received his Ph.D. from the University of Notre Dame for his work on the place of anger in the Thomistic theory of the passions. He is the author of Introducing Moral Theology: True Happiness and the Virtues, and the editor of New Wine, New Wineskins: A Next Generation Reflects on Key Issues in Catholic Moral Theology. 
relevant for Catholic higher education. Marian claims, “This paper proposes that friendship and contemplation share the same rootedness in relationship and pursuit of understanding, and so can serve as the fundamental context from which the transcendent hope and power of the liberal arts might flourish for all members of the campus community" (2). She first examines these two topics in three of my favorite thinkers-Aristotle, Augustine, and Thomas Aquinas-before turning to examine the relationship between the two topics, and finally identifying some areas for further exploration. I'll draw on her work all throughout, and hopefully complement it with these reflections.

This response will proceed as follows. I'll first address contemplation. I'll continue Marian's thoughts on the active and contemplative lives and turn also to the anthropological rationale for the primacy of the contemplative. My own alma mater, Georgetown, lists contemplation in action as characteristic of Ignatian spirituality and education, and I think reflection on this phrase will help continue some of what Marian addressed. It will also provide some guidance on how to avoid certain shoals which are particularly dangerous in navigating university life. Next I'll turn to friendship. Some of Marian's most powerful and poignant words concern friendship, and I won't hope to augment those here. What I would like to do is to complement the previous section's conclusion - which ends up being the priority of the truth to the good, the intellect to the will—with an exploration of how, particularly in the most important areas of life, the intellect on its own is inadequate, and relies on the will—or better, knowledge relies upon love. In these venues, friendship is an indispensable engine of learning, of contemplation as Marian noted. And thus friendship plays a crucial intellectual-dare I say epistemological—role in the life of the university.

After these two main points, I'd like to turn to treat a topic raised frequently by Marian's paper but to which she was unable to give extended attention, namely the presence of people with different or no faith on our campuses. I'd like to suggest that Marian's thoughts on friendship are a phenomenal place to start reflection on how a Catholic university can be both fully and truly hospitable, and fully and truly evangelical. We'll find that the emphasis on friendship is the key to being both of these.

\section{Contemplation}

So first, contemplation and the transcendent value-or better, hope-of a liberal arts education. Marian's paper explains the enormous importance that ancients and medievals afforded to contemplation. Marian's paper is full of quotes and references offering superlative descriptions of contemplation. It is the final end-all other aspects of life serve it. She quotes Aquinas in saying it is by the contemplative life that man is guided to God (7). In terms of the gospel, she rightly recounts the story of Martha and Mary as interpreted by Augustine and others to say that contemplation is the highest way of life. But what exactly is going on here with this claim?

Many of us no doubt imagine the gospel story as Martha faithfully places herself at the service of her guests, while Mary idly (lazily even?) rests at the Lord's feet and leaves 
the serving to others. Is that the "better part" referenced by Jesus? Clearly this cannot be the case.

What is it then? I think of occasions in my own home where at our weaker moments, preparation for an event, or for guests, can actually impede the very goal that it is supposed to serve. When getting things "just so" disrupts our ability to enjoy our time with company-or worse when it engenders discord among the hosts and therefore impedes hospitality - in these examples the activity of preparing for guests impedes the goal it is supposed to serve.

To continue the examples from domestic life, I think in my life as a parent of how at times I can be quite concerned and efficient with getting things done in taking care of the kids, perhaps if my wife Courtney is working late and I'm alone with our sons Billy and Jack after school. I can prepare dinner, oversee homework, tend to the home, and prepare for the next day (lunches, baths, etc.). It is easy for me to let even this noble and well-intentioned activity actually impede the supposed point of that activity, namely, to live our lives as a family together, in loving communion. I can become impatient, frustrated, and snap at the very children I purport to be serving.

In these cases, the problem is not practical activity per se. Of course that is necessary and good. It is our busy activity losing sight of its point, or becoming the point in itself. We see this all the time in our students as well, who are so overscheduled with laudable activities that it is a wonder if they can grow in wisdom and form fruitful friendships and relationships. We surely see it in us administrators, who can be so focused on what to do next and what programs to start that we can at times forget the goals these endeavors are supposed to serve.

In classical thought, the active or practical life is recognized as seeking further goods while the contemplative life is an end in itself. While the practical life is activity in search of (hopefully laudable) goals, the contemplative life is resting in the presence of what is sought. It is fulfillment, enjoyment. The traditional interpretation of the Martha and Mary story is not that laziness is to be preferred to active service. It is rather that activity should never eclipse its further goal, in this case resting in friendship and conversation with the Lord. Thus one way we can further support Marian's emphasis on the importance of contemplation is to keep first things first, to remember the goal, and what is in service to that goal. That way we will not allow our important goals to be eclipsed by activity that purportedly serves those goals. In doing so we will not cease to be active. We will rather embody that Ignatian phrase "contemplatives in action" by keeping our eyes on the prize and allowing our activity to be shaped, to be formed, accordingly.

There is another way the ancients and medievals understood the active and contemplative. The active is associated with what we (with Aquinas) could call the appetitive facet of human life. "Appetitive" is not a reference to eating, but rather to that facet of us that yearns for and seeks the good. The appetitive is the part of us that seeks the good, with our passions but especially with our wills. The contemplative is associated with what we might (again with Aquinas) call the apprehensive part of our 
human nature. "Apprehensive" is not a reference to anxiety, but rather to our capacity to apprehend or grasp reality. With apprehensive powers like our senses and especially our intellects we grasp the truth. ${ }^{2}$

What does all this anthropological reflection have to do with the excellence of contemplation? It is this. The priority of contemplation is a reminder that-to use Josef Pieper's synopsis of Aquinas - the true precedes the good. ${ }^{3}$ All of our plans, projects, and practical endeavors - no matter how exalted - must reflect and be rooted in the truth in order to be genuinely good. Marian's turn to contemplation as a main marker of a liberal arts university is a reminder that the true precedes the good. That as much as we all strive to make our universities forces for good in the world, for our students and other community members, that "project" is born from, reflects a grasp of, and is ultimately servant to the truth.

This is the very essence of contemplation in action. Not contemplation as fleeing from the world. Not contemplation as self-absorption or elitism. But activity that is reflected upon, refined, honed, shared, explained, revised, and then all over again. All of us are familiar with the famous Socratic dictum that the unreflective life is not worth living. I certainly wouldn't endorse that wording. Yet I think it fair to say that the most fully alive, human life is a reflective one. Not only in a university setting, of course. But the university is a place where this priority should particularly be cherished and reflected and witnessed. Marian rightly reports that for Aristotle and others the life of contemplation was an end in itself. This can sound elitist and self-absorbed-and of course it may have been instantiated in precisely such a way for Aristotle or others Marian addresses. But at its heart, the focus on contemplation is a recognition of the primacy of the truth.

\section{Friendship}

In addition to following Marian's analysis, there is an easy transition to the topic of friendship from the foregoing since the venue where reflection most commonly happens in life is not in a formal university setting, but in friendships. In kitchens, at barstools, on assembly lines, in cafeterias. Wherever friends share their lives and in doing so reflect upon them. But Marian is right to point out that the university is a place where friendships are absolutely crucial. She adeptly recounts the importance of friendship to Aristotle as well as other ancients. She notes how Aquinas-with appeal back to Aristotle-uses friendship as a way to better understand that most exalted of Christian activities: charity and love of God and neighbor in God. And of course anyone who works with college students can join Marian in this recognition given the enormous role that friends play in the lives of undergraduates-for good and bad! Friendship is crucial for Catholic higher education.

\footnotetext{
2 For more on this distinction as well as the priority of apprehension / truth to appetite / will in the attainment of happiness, see St. Thomas Aquinas, Summa Theologiae I-II 3,4.

3 Josef Pieper, The Four Cardinal Virtues (South Bend, IN: University of Notre Dame Press, 1966), 4.
} 
I'd like to continue that topic with two points here. And I'd like to appeal to Pope Francis's first encyclical, Lumen Fidei, to do so. ${ }^{4}$ The first point is this: Friendship is not simply an accidental, ornamental accompaniment to a liberal arts education. It is an engine for knowledge. It is epistemologically essential in the most important types of knowledge. Pope Francis describes this in his encyclical with regard to faith and other types of knowledge as well. We might see this point better if we say "trust" rather than faith or belief. Trust is essential to the acquisition of knowledge. Pope Francis reminds us how this is true with regard to architects, pharmacists, and lawyers. ${ }^{5}$ When we proceed on a course of treatment, or plan for our house, or legal defense-even if we use WebMD, WebJD, or the architectural equivalent-we do so trusting those who guide us. This is not simply a matter of willful acquiescence or obedience. We actually see things differently based on this trust and thus act accordingly. We are formed in these relationships by what we take to be true. In these cases, knowledge can be called "personal" not because it is primarily about persons, but because a personal encountertrust-is the engine that prompts our assent to things as true. ${ }^{6}$

Obviously Pope Francis goes on to make the point that religious belief is not a form of knowledge unlike any other; it is assenting to things as true due to personal relationships, and it has this in common with other venues of trust even if in the case of faith the personal relationship is with Christ Himself through the Church, which is us, the Body of Christ and People of God. Personal relationships are essential to such knowledge. But the point holds about other important types of knowledge as well.

This, friends, is why friendships are so important at college. Part of the reason going to a high-quality school is effective is the academic caliber of one's student peers. And we all know how influential a student's friends are in their studying-or not. But I'm not actually talking about these more indirect influences of friendship. I'm talking about the trust between friends that is the engine of learning. This is most obvious with professors and students. You don't need to read Parker Palmer to know that as important as good curriculum and pedagogical technique is for college teaching, a crucial element for effective teaching is trusting the professor.7 Frankly, even when the student dismisses the professor as a nut, he or she still trusts that the material presented is true. But when a student trusts a professor personally, the impact that professor can have on the student's life is extraordinary. Presumably all of us have had such occasions or we would not be here. Of course, this privileged relationship can be used well or, God forbid, be destructive, as happens in some parent-child, or spousal, or priest-child relationships. But that potential for harm should only make us more committed to being attentive to

4 Pope Francis, Lumen Fidei (The Light of Faith), June 29, 2013, at http://www.vatican.va/holy_father/ francesco/encyclicals/documents/papa-francesco_20130629_enciclica-lumen-fidei_en.html.

5 Lumen Fidei, 18.

6 Lumen Fidei, 29.

7 Very influential on my own teaching has been Parker Palmer's The Courage to Teach: Exploring the Inner Landscape of a Teacher's Life (Jossey-Bass, 1998). 
enabling that trust to lead our students to a more truthful grasp of the field at hand, the world, themselves and others, and ultimately God. Personal relationships as described by Marian, friendships, are essential to learning.

My second point on friendships, one which Marian repeatedly references, is this: Friendship is not simply an instrument for gaining knowledge, but a very participation in the end of contemplation. As Marian put it with regard to Aristotle, "Friends share the end....Their partnership [and she helpfully notes the Greek there is koinonia, used by Aristotle but with an explosive range of meaning for Christians ${ }^{8}$ ] will surely be a sharing in that end" (emphasis added) (5). The way I like to word this is, the medium is the message.

Once again I direct us to Lumen Fidei, where Francis [I think comically] quotes Jean Jacques Rousseau's exasperation with not being able to grasp the truths of faith immediately on his own: "How many people stand between God and me!"...."Is it really so simple and natural that God would have sought out Moses in order to speak to Jean Jacques Rousseau?"9

Well yes. Faith is true knowledge of, a very apprehension of God (even if, of course, not full comprehension). If faith could be obtained immediately, without others, in a manner subject to our control, it would be a different sort of faith and a different sort of God. Friendship with others, and the abiding relationships through time that Pope Francis associates with the metaphor of hearing, are not simply tools to gain knowledge. If they were, Rousseau would be right, and God's ways of inviting us to know him would be quixotic; inefficient at best. Rather, the medium is the message. Friendship is a very participation in the answer, which even for Aristotle was friendship and political community, and of course for Christians it is the communion of self-giving love with the Triune God and others that we call the communion of saints. Marian says at one point that we need to help cultivate authentic relationships in our universities. Amen. And not only because they make college more enjoyable, which they do. And not even because friendships make studying more enjoyable, or because they are an engine for gaining knowledge, which they are. But most of all because communion with others-and we Christians trust that loving communion is the real presence of God-is the point of it all.

Needless to say, I fully agree with Marian that friendship is at the heart of liberal arts education. Indeed, there is a way we can say it is the point of it.

\section{Christians and non-Christians}

Let me say a word to the matter of Catholics, non-Catholic Christians, people of other faiths, and people of no religious faith on our campuses. In her opening paragraph, Marian mentions how "the context of Catholic higher education also includes persons of all faiths and persons of no faith" (2; see also I5). In a time when Catholic institutions are called to reflect on their Catholic identity, it can seem that doing so is antithetical to

8 This term is best translated "community," which has a more personal connotation than "partnership." Several New Testament authors use the same word in reference to the communion of the Church. 
a capacious hospitality to non-Catholics. I'm reminded also of our conversation about how, or really whether, Catholic universities educate differently than secular schools. I think this last point on friendship provides a way to address how a common educational endeavor can be genuinely shared by people of different faiths and yet that very endeavor be a possibility for evangelization, a word that can seem anathema to those calling for attention to pluralism but which yet must surely be at the heart of any Catholic institution. How can this be a both / and? ${ }^{\text {Io }}$

The centrality of friendship in the educational endeavor is not at all something unique to Catholics. Can Harvard University graduate people who are nourished educationally by friendship and well-formed morally, ethically? Of course. The commitment to friendship, the common good, and communal flourishing are things that we thankfully can and do share with our friends of other (or no) faith. Yet the same endeavor can also be evangelical, a venue for encountering the good news of Christianity. Why? Because self-giving loving communion of persons is the heart of our faith. It is who God is. It is the destiny for which we were created. It is how we are enjoined to live and flourish. As Marian notes, Aquinas wisely perceived in describing love of God and others in God as friendship: this is what it is all about. "I call you friends" (Jn I5:I5). Where there are friends, God is present. What better focus is there for our Catholic institutions of learning to have than friendship, which not only is the engine for growth in wisdom but is a very participation in the divine life, and thus a powerful agent of evangelization, even when the friendship is not at this time lived in the context of explicit faith?

To conclude, needless to say I was thrilled to read Marian's paper. Not only does she help specify a tricky theme, she does so in a way that offers two topics-and friendship in particular - that are at the heart of our Catholic tradition and at the heart of the mission of the university.

10 Like so many theological matters today, this one rests on an accurate understanding of the relationship between nature and grace, along with a non-competitive understanding of the relationship between divine and human agency, which is a topic for another time even though not far beneath the surface here. 